\title{
Kampen om matfatet og matproduksjonen
}

\author{
Hans Morten Haugen
}

Institutt for diakoni og ledelse, Diakonhjemmet Høgskole, haugen@diakonhjemmet.no

Antallet sultne $i$ verden har økt, selv om det kan diskuteres om det $i$ dag er en høyere eller lavere andel som lider under sult enn for seks år siden - før matprisøkningen. Alle er uansett enige om at det samlet sett produseres nok mat $i$ verden til at alle kan få dekket sine ernoringsbehov. Artikkelen viser at to hovedretninger $i$ debatten om matproduksjon står mot hverandre. Den dominerende retningen fokuserer primœert på matsikkerhet, forstått som økt matproduksjon og økt handel med mat. Den andre retningen argumenterer for at interessene og rettighetene for de mest sårbare må ha forrang i politiske prioriteringer, og at de sårbare sikres best med en strategi basert på menneskerettigheter. Artikkelen drøfter landfordeling, økt bruk av genteknologi i landbruket og nedbygging av handelshindre for landbruksprodukter. Industrialisering av landbruket og liberalisering av handelen med landbruksvarer kan gi gode resultater på makronivå - på kort sikt. Dersom målet er å fremme situasjonen for de mest sårbare og samtidig møte klimautfordringene er løsningen en nedenfra-tilnoerming, som til nå er blitt ignorert av de fleste stater.

Nøkkelord: retten til mat, matsikkerhet, klima, Verdens handelsorganisasjon, FNs tusenårsmål

\section{English summary: The struggle over food intake and food production}

The number of hungry persons in the world has increased - although it is debatable whether there is currently a higher or lower proportion of suffering from hunger than six years ago before the food price increases. All agree that the overall production of food in the world is adequate for everyone's nutritional needs. The article demonstrates that there are two main approaches in the debate on food production. The dominant approach focuses primarily on food security, understood as increased food production and increased food trade. The other approach argues that the interests and rights of the most vulnerable must prevail, and that improvements for the vulnerable are best ensured with a strategy based on human rights. The article analyzes land distribution, increased use of genetic technology in agriculture and reduction of trade barriers for agricultural products. Industrialization of agriculture and the liberalization of trade in agricultural products can provide good results at the macro level - in the short term. If the goal is to promote the situation of the most vulnerable and at the same time addressing climate change, the solution is a bottom-up approach, which until now has been ignored by most states.

Keywords: the right to food, food security, climate change, World Trade Organization, UN Development Goals 


\section{Innledning}

Hvordan er det mulig å endre på det faktum at anslagsvis 870 millioner mennesker i verden i dag lider av kronisk underernæring eller sult (FAO 2012a)? ${ }^{1}$ Andelen mennesker som lider av sult, har faktisk gått noe ned de siste 20 årene, men samtidig er det flere personer som sulter, til tross for at alle er enige om at det globalt produseres nok mat til at alle kan få dekket sine ernæringsbehov.

Sen (1981) understreker at en stats politikk må vurderes ut fra hvorvidt den gjør innbyggerne i stand til å skaffe seg mat og slik bli fri fra sult. Denne forståelsen har, selv om den ikke er eksplisitt forankret i en menneskerettighetsstrategi, gitt betydelig inspirasjon til en bedre forståelse av hvordan retten til mat best kan realiseres. Et avgjørende punkt er reell tilgjengelighet («accessibility»), ikke bare samlet matproduksjon («availability») (CESCR (FNs komité for økonomiske, sosiale og kulturelle rettigheter) 2000: avsnitt 8, 12-13).

Sen (1981) og moderne menneskerettighetsstrategier har det til felles at de begge vektlegger at mennesker og lokalsamfunn må få større kontroll over sine omgivelser, omtalt som myndiggjøring. Økt myndiggjøring er også en sentral målsetting for en god utviklingsprosess. Den norske regjeringen sier at utviklingspolitikk «handler om å skape en situasjon der folk har kontroll over egne ressurser og kan kreve rettigheter» (Utenriksdepartementet 2009: 13). Norske myndigheter bekrefter dermed en menneskerettighetsbasert tilnærming til utvikling, der kontroll over egne omgivelser, inklusive naturressurser, er sentralt for at en positiv utviklingsprosess skal finne sted. Denne erkjennelsen er likevel ikke enerådende. Som vi skal se i denne artikkelen, er det svært ulike forståelser av hva som er det mest effektive for å forhindre sult, og hvorfor tallet på mennesker som sulter ikke har gått ned - selv om økningen i global matproduksjon har vært raskere enn økningen i globalt folketall de siste tiårene.

I denne artikkelen vil jeg først ha en gjennomgang av innholdet i retten til mat og de avledede pliktene for statene, og deretter vise hvordan ulike forståelser av effektive tiltak for å forhindre sult kan illustreres ved hjelp av det analytiske rammeverket matregime. Et matregime er definert som en «rule-governed structure of production and consumption of food on a world scale» (Friedman 1993: 30-31). Deretter følger en vurdering av konkurrerende matregimer slik disse presenteres av Holt-Gimenez (2010:3) på tre ulike saksområder: landfordeling, bruk av genteknologi og internasjonal handel med mat. Også menneskerettigheter blir trukket inn i vurderingen av hvert saksområde. Avslutningsvis vil jeg forsøke å gi forklaringer på hvorfor landbruket er blitt stemoderlig behandlet.

Artikkelen bygger på at ethvert politisk og økonomisk system og enhver beslutning må vurderes ut fra hvilken effekt det har for dem som er mest sårbare og marginaliserte. I en situasjon der mange husholdninger bruker 70 prosent av inntektene på mat, vil $ø$ kninger i matprisene ramme særlig hardt. Statene bes om å rapportere særlig om situasjonen for to grupper mennesker: landløse småbønder og personer som tilhører minoriteter (CESCR 2009: avsnitt 46). Tiltak som bedrer disse menneskenes situasjon på kort og lang sikt, må prioriteres.

Samtidig er det lave inntekter blant mange som arbeider i landbruket. Halvparten av dem som lider av sult, er selv bønder (FNs menneskerettighetsråd 2012: avsnitt 17), og 
dersom man tar med alle dem som arbeider i landbruket, er sju av ti av dem som sulter, involvert i landbruksproduksjon.

Den produksjonen disse bøndene og dagarbeiderne står for, foregår uten at myndighetene sikrer god tilrettelegging. Ofte er det vanskelig tilgang på land, vann, frø og andre innsatsfaktorer (FNs menneskerettighetsråd 2012: avsnitt 17), og dersom private frøselskaper er til stede på markedet, er det ingen som etterser at bøndene blir tilstrekkelig informert til å gjøre sine valg. Selv om det økonomiske handlingsrommet for verdens fattigste stater tilsynelatende ikke er stort, kan myndighetene i disse statene likevel lære av tiltakene knyttet til landbruket som for flere tiår siden ble initiert i stater som i dag er rike (Chang 2009).

Selv om det globalt produseres nok mat, er det avgjørende at det skjer en økning i matproduksjonen i de statene der befolkningen vil fortsette å vokse. Dersom dette ikke skjer, blir disse statene i enda større grad enn i dag avhengige av matvareimport. Det er et betydelig potensial for produksjonsøkning i disse statene, men utfordringen er at de i dag opplever konsekvensene av klimaendringer, med vannmangel og tørke. Særlig viktig er det å sikre bønder bedre tilgang til ressurser til matproduksjonen som er tilpasset slike forhold, og at markedene fungerer bedre for både kjøper og selger (Chang 2009). Selv om matutdeling vil være nødvendig i gitte situasjoner for å sikre at alle får tilstrekkelig og sunn mat, er dette både dyrt, avhengighetsskapende og ødeleggende for lokalt produksjons- og næringsliv. For å sikre retten til mat er det viktigste å gjøre den enkelte bonde bedre i stand til å øke produksjonen.

\section{Retten til mat}

Menneskerettighetene er en minimumsstandard for hva som kjennetegner et liv i verdighet. Det er to forhold med menneskerettighetene som er verdt å merke seg. For det første er menneskerettighetene formulert av statene selv, det er de som har bestemt innholdet $\mathrm{i}$ standardene. Retten til mat handler om å sikre alle fysisk og økonomisk tilgang til nok, trygg og næringsrik mat, eller til midler til å kjøpe slik mat (CESCR 2000: avsnitt 6; FAO 2004: avsnitt 16). Disse elementene er også sentrale i den definisjonen av matsikkerhet som statene ble enige om under Verdens mattoppmøte (FAO 1996: avsnitt 1). For det andre er menneskerettighetene en del av internasjonal rett, og gjennom å ratifisere konvensjoner pålegger statene seg folkerettslige plikter.

Vi skal her kort presentere innholdet i retten til mat, før vi i neste del ser på de avledede plikter for statene.

For sosiale menneskerettigheter er det vanlig å operere med et skille mellom rettighetenes kjerneinnhold og rettighetenes tilleggsinnhold. Kjerneinnholdet i retten til mat kan formuleres som retten til å være fri fra sult, som anerkjennes i FNs internasjonale konvensjon om økonomiske, sosiale og kulturelle rettigheter (ØSK-konvensjonen, FN 1966), artikkel 11.2. Dette er den eneste menneskerettigheten som omtales som «grunnleggende» («fundamental»). 
For den mer generelle retten til mat - som er anerkjent i ØSK-konvensjonen (FN 1966), artikkel 11.1, om rett til en tilfredsstillende levestandard - har FNs komité for økonomiske, sosiale og kulturelle rettigheter (CESCR) definert at maten skal være kulturelt akseptabel (CESCR 2000: avsnitt 11). En slik innholdsbestemmelse går lenger enn hva ordlyden i konvensjonen gir grunnlag for.

Selv om retten til mat er anerkjent på individnivå, er også rettigheter for folk, inklusive urfolk, anerkjent i ØSK-konvensjonen (FN 1966), artikkel 1.2: «Alle folk kan for å fremme sine egne formål fritt råde over sine naturrikdommer og -forekomster [...]. Ikke i noe tilfelle må et folk bli berøvet sitt eget eksistensgrunnlag.» Ordet eksistensgrunnlag må forstås å omfatte alt som et anerkjent folk er avhengig av for sin overlevelse, inklusive matplanter. Folkenes rett over sine naturrikdommer må sikres i møte med omfattende ressursutvinning, miljøødeleggelse eller andre inngrep.

Sentralt for retten til mat er at denne primært realiseres ved at bøndene får gode og forutsigbare betingelser, slik at de kan øke sin matproduksjon. Videre må den maten som produseres, gjøres mest mulig og raskest mulig tilgjengelig for forbrukerne, og ikke forringes eller ødelegges som følge av dårlig bearbeiding eller lagring. Det er altså en sammenheng mellom framstilling, oppbevaring og distribusjon. Samtidig vil en produksjonsøkning som ikke resulterer $\mathrm{i}$ at maten faktisk blir mer tilgjengelig for dem som trenger det, ikke i seg selv sikre realisering av retten til mat.

Matmangel er særlig skadelig for barns fysiske og intellektuelle utvikling, der over en fjerdedel av barna er veksthemmet som følge av for lite mat (UNICEF, WHO \& Verdensbanken 2012). FNs menneskerettighetsråd sier at verdens sultsituasjon er en krenkelse av menneskelig verdighet (FNs menneskerettighetsråd 2012: avsnitt 1). Det er ikke vanlig å omtale menneskerettighetsbrudd som krenkelser av menneskelig verdighet, men til tross for disse erkjennelsene reduserte statene i år 2000 sine ambisjoner om å redusere tallet på sultne, sammenlignet med den ambisjonen som ble uttrykt under Verdens mattoppmøte i 1996. Den ambisjonen som er uttrykt i tusenårsmålsetting $1 \mathrm{C} \mathrm{om} \mathrm{å} \mathrm{halvere} \mathrm{andelen}$ sultne fra 1990-nivået innebærer faktisk at verdens statsledere i 2000 aksepterte at 200 millioner flere er sultne i 2015 enn det som lå i 1996-målsettingen. ${ }^{2}$

\section{Plikter for statene}

Menneskerettighetene stiller også opp plikter for statene, nedfelt i artikkel 2.1 i ØSK-konvensjonen (FN 1966). Istedenfor å ha en detaljert gjennomgang av denne bestemmelsen skal vi se på nyere forståelser av hva disse pliktene rommer. Særlig sentral er typologien som først ble utviklet av Asbjørn Eide (1987), om å respektere (ikke intervenere), beskytte (hindre andre fra å intervenere) og oppfylle (gjennom å tilrettelegge og eventuelt besørge). Særlig når det gjelder retten til mat, er det mest effektivt å la den enkelte bonde selv velge sin produksjonsform og omsetningsform. For at denne produksjonen og omsetningen skal bli mest mulig effektiv, må imidlertid staten spille en rolle.

Tilretteleggingen for realisering av retten til mat handler blant annet om fungerende infrastruktur, gode lover og institusjoner. I tillegg, som vi så over, er det avgjørende med 
tilgang på land, vann, frø og andre innsatsfaktorer. Kort fortalt, ved å prioritere effektiv fordeling av gode innsatsfaktorer kan staten sikre en tilstrekkelig stor matproduksjon til at det ikke blir nødvendig med tiltak for å fordele mat.

Det skilles mellom evne og vilje for å presisere når en stat ikke har oppfylt pliktene sine. Dersom det er manglende ressurser - vidt forstått - som gjør det umulig for staten å sikre retten til mat for alle sine innbyggere, kan ikke staten anklages for å ha krenket menneskerettighetene. Her er det imidlertid viktig å minne om at internasjonale ressurser er en del av den potensielle ressursbasen til statene (CESCR 1991: avsnitt 13-14; Maastricht Principles 2012: avsnitt 31). Internasjonalt samarbeid som middel til å realisere retten til mat understrekes i ØSK-konvensjonen (FN 1966), artikkel 11.1-2. Stater som nekter å samarbeide, eksempelvis når det er en reell sultsituasjon, kan bli funnet å ha krenket retten til mat.

Internasjonalt samarbeid handler også om innsats for å utvikle mer høytytende og tilpassede plantesorter samt andre tiltak for å øke matproduksjonen i stater hvor produksjonen er langt mindre enn potensialet. Et eksempel er bekjempelse av parasittiske planter som striga, som ødelegger avlinger i en rekke afrikanske land. Bekjempelse av striga skjer ikke ved å bruke avansert genteknologi, men ved å plante desmodium, som dreper strigaplantene før de kommer i kontakt med matplantene.

FNs komité for økonomiske, sosiale og kulturelle rettigheter (CESCR) understreker at alle stater - også de med begrensede ressurser - må treffe målrettede tiltak for å oppfylle forpliktelsene i konvensjonen (CESCR 1991: avsnitt 1-2). I tillegg kommer en generell plikt til å treffe alle nødvendige tiltak for å avskaffe diskriminering i lovgivningen (de jure) og det faktiske liv (de facto).

Den kanskje største verdien av en menneskerettighetstilnærming er at statene ansvarliggjøres både for prosessen og for selve resultatet. CESCR omtaler dette som «atferdsforpliktelser» og «resultatforpliktelser» (CESCR 1991: avsnitt 1). En annen måte å omtale atferdsforpliktelser på er gjennom begrepet menneskerettighetsprinsipper. Slike prinsipper er utledet av de substansielle menneskerettighetene (Haugen 2011) og handler om minimumsstandarder for en god beslutningsprosess. Slike menneskerettighetsprinsipper ble nevnt av CESCR (2000: avsnitt 23) og står blant annet i de frivillige retningslinjene for landrettigheter (FAO 2012c: prinsipp 3B). De fleste som omtaler menneskerettighetsprinsipper, viser til FN-organenes Common Understanding (FN 2003). Problemet med denne listen er at den inkluderer prinsipper som er av så overordnet karakter at de ikke kan sies å utgjøre minimumsstandarder for en god beslutningsprosess. I tillegg er ikke myndiggjøring med i listen. Myndiggjøring som gjør den enkelte og lokalsamfunnene bedre i stand til å ta ansvar for sine liv, må være målet for enhver menneskerettighetsstrategi og utviklingsstrategi, og må derfor også regnes som et menneskerettighetsprinsipp.

I mangel av en rettslig bindende katalog over menneskerettighetsprinsipper kan FAOs liste med sju menneskerettighetsprinsipper være nyttig (FAO 2007: 2): verdighet, ikke-diskriminering, rettsstyre, ansvarlighet, åpenhet, deltakelse og myndiggjøring. De to første er kjernen i menneskerettighetene - det man ønsker å oppnå ved å realisere menneskerettigheter. De tre neste handler om hva staten må sikre (ovenfra-perspektiv), mens de to siste handler om hva innbyggerne må ta ansvar for (nedenfra-perspektiv). Dette viser at ingen mennes- 
kerettighetsrealisering primært handler om at innbyggerne skal kreve at staten skal dele ut goder. Staten skal sørge for gode rammer for den enkeltes trygghet, livsutfoldelse og erverv.

Selv om det kan hevdes at retten til mat rommer mange elementer, er altså kjernen at staten har en plikt som tilrettelegger, også ved å beskytte individer og lokalsamfunn mot maktovergrep fra mektige aktører. Private selskaper har et selvstendig ansvar i å respektere menneskerettighetene og ikke selv bidra til krenkelser, men de har ingen folkerettslig plikt på samme måte som statene.

\section{Matregimer}

Som omtalt i definisjonen av matregime over (Friedman 1993) er matregimer et analytisk rammeverk for å studere matproduksjon og -forbruk på globalt nivå. Mens de opprinnelige analysene studerte hva som kjennetegnet matregimer i gitte epoker, er det nå en erkjennelse av at flere matregimer kan eksistere parallelt og være innbyrdes motsetningsfulle (McMichael 2009). Videre er det viktig å påpeke at matregimer har vært forankret i marxistisk forståelse, men det er ikke like tydelig i de nye kategoriseringene (HoltGiménez \& Shattuck 2011; Holt-Giménez 2010).

\begin{tabular}{|c|c|c|c|c|}
\hline & Nyliberal & Reformistisk & Progressiv & Radikal \\
\hline Diskurs & Matforetak & Matsikkerhet & Matrettferdighet & Matsuverenitet \\
\hline Stikkord & $\begin{array}{l}\text { Bedriftsutvik- } \\
\text { ling }\end{array}$ & $\begin{array}{l}\text { Samfunnsutvik- } \\
\text { ling }\end{array}$ & Myndiggjøring & $\begin{array}{l}\text { Kontroll over } \\
\text { ressurser }\end{array}$ \\
\hline Tilnærming & $\begin{array}{l}\text { Industribasert } \\
\text { produksjon, } \\
\text { storselskaper } \\
\text { kontrollerer } \\
\text { hele verdikje- } \\
\text { den, landopp- } \\
\text { kjøp, enkel } \\
\text { adgang til gen- } \\
\text { modifisering }\end{array}$ & $\begin{array}{l}\text { Promotering av } \\
\text { mellomstore en- } \\
\text { heter, ønske om } \\
\text { genmodifisering } \\
\text { ut fra behov for } \\
\text { særlig næringsrik } \\
\text { mat og planter } \\
\text { som er mot- } \\
\text { standsdyktige } \\
\text { mot klimaendrin- } \\
\text { ger }\end{array}$ & $\begin{array}{l}\text { Retten til mat, } \\
\text { bedre sosialt } \\
\text { sikkerhetsnett, } \\
\text { bærekraftig } \\
\text { produsert mat, } \\
\text { agroøkologisk } \\
\text { produksjons- } \\
\text { form }\end{array}$ & $\begin{array}{l}\text { Matsuvereni- } \\
\text { tet for stater og } \\
\text { folk, bærekraf- } \\
\text { tig og kulturelt } \\
\text { akseptert mat, } \\
\text { økt innflytelse i } \\
\text { forhandlinger }\end{array}$ \\
\hline
\end{tabular}

Kilde: Holt-Gimenéz 2010: 3 (forenklet framstilling)

Hver av disse retningene skal kort omtales, i den rekkefølgen de framtrer i oversikten.

Matforetak er den tilnærmingen som vokser fram blant annet ved at store matselskaper etablerer kontroll over hele produksjonskjeden («vertikal integrasjon»). ${ }^{3}$ 
Matsikkerhet er den tilnærmingen som dominerer i internasjonale fora. Det handler om mengden mat som produseres og den enkeltes tilgang til denne maten. Likevel rommer ikke matsikkerhet eksplisitte forventinger til god beslutningsprosess for å hindre at individer og lokalsamfunn rammes, slik vi har sett at menneskerettighetene gjør.

Matrettferdighet er den mest vidtfavnende kategorien og omfatter alt fra "fair trade» via «slow food» til lokale matorganisasjoner (Holt-Gimenéz 2010: 3). Som vi ser, er menneskerettigheter sentralt innenfor denne diskursen. Videre er myndiggjøring, som vi har sett er et sentralt menneskerettighetsprinsipp, altså hvordan individer, husholdninger og lokalsamfunn blir i stand til å mestre sine liv og omgivelser, funnet å beskrive matrettferdighetsmodellen best (Holt-Gimenéz 2010: 3).

Matsuverenitet er omtalt i ett dokument vedtatt av stater, og defineres som «retten for folk og suverene stater til å demokratisk bestemme sin egen landbruks- og matpolitikk» (IAASTD 2009: 5). Storbritannia uttrykte reservasjon, med den begrunnelsen at det ikke eksisterer en internasjonal definisjon av matsuverenitet (Holt-Gimenéz 2010: 12). Begrepet matsuverenitet kan kritiseres for ikke å inneholde en tilstrekkelig klar definisjon av hva som inngår i begrepet, og hvem som er subjekter og rettighetshavere (Haugen 2009). Likevel, ved å legge vekt på rettigheter for folk og kontroll over ressurser er forståelsen av matsuverenitet i stor grad sammenfallende med innholdet i folks rett over sine naturressurser, som anerkjent i artikkel 1.2 i ØSK-konvensjonen (FN 1966).

Vi skal nå se på tre forhold ved matproduksjon og -forbruk for å finne ut hvordan de fire skolene i rammeverket utviklet av Holt-Gimenéz betrakter disse, og vi vil også se hvordan disse tre forholdene forstås innenfor en menneskerettighetsstrategi. De tre forholdene er storskala landbruk, genmodifisering og økt handel med mat. Den kjente utviklingsøkonomen Paul Collier (2008) hevder at løsningen på verdens sultkrise ligger i industrilandbruk, full bruk av genteknologi og nedbygging av handelshindringer for landbruksvarer, og han har fått støtte fra blant annet Erik Solheim. ${ }^{4}$

\section{Storskala landbruk}

Promotering av langt større enheter i landbruket er basert på at mange småbønder har for liten produksjon til å kunne brødfø seg og sin familie og i tillegg legge seg opp et overskudd. Det er vanskelig å være kategorisk uenig i at enheter på 10 dekar, særlig dersom eiendommen ikke er sammenhengende, er lite effektivt. Strukturendringer er derfor nødvendig i mange land. Hege Hertzberg, leder i Analyseenheten i Utenriksdepartementet, har uttalt: «Det er alt for mange bønder i Afrika [...]. De har for små åkerlapper til at det er mulig å oppnå en god levestandard» (Utviklingsfondet 2012).

Det Collier (2008) tar til orde for, er imidlertid langt mer dramatisk enn å legge til rette for mer rasjonelle enheter. En generell omlegging til plantasjelandbruk vil gi flere hundre millioner arbeidsløse. Plantasjedrift vil som regel innebære en langt mindre arbeidsintensiv produksjon, selv om det er betydelige ulikheter, der maskinell høsting av soya og 
manuell kutting av sukkerrør representerer ytterpunktene. Collier (2008) hevder at de som blir overflødige på landsbygda som følge av denne omleggingen, kan søke arbeid i byene - uten at han problematiserer de enorme sosiale konsekvensene av en slik massiv flytting inn til slumbyer som allerede er overfylte.

I Afrika er arealer som samlet sett representerer $343000 \mathrm{~km}^{2}$, enten solgt eller leid ut på langtidskontrakter fra 2000 til 2010 (Anseeuw mfl. 2012: 23). En studie har funnet at svak anerkjennelse av landrettigheter i en stat medfører økt omfang av landoppkjøp eller langtidskontrakter (Deininger \& Byerlee 2010: 55). Andelen utenlandske investorer varierer fra 3 prosent i Nigeria til 93 prosent i Liberia (Cotula 2012: 656). Trenden er likevel at utenlandske oppkjøpere i Afrika ofte får tilgang til større områder enn lokale oppkjøpere.

Uten å gå i detalj handler slike landoppkjøp ofte ikke primært om å sikre mattilgang for afrikanerne selv. I Afrika er 66 prosent av alle landoppkjøp eller kontrakter om langtidsleie av jord knyttet til produksjon av biodrivstoff, mens bare 15 prosent er knyttet til matproduksjon (Anseeuw mfl. 2012: 25). På globalt nivå er disse tallene henholdsvis 40 og 25 prosent (Anseeuw mfl. 2012: 24). Samtidig er det verdt å merke seg at på bare 21 prosent av alle landområdene som er overdratt, er det startet noen form for produksjon, og ofte i et langt mindre omfang enn opprinnelig angitt (Deininger \& Byerlee 2010: 52).

Disse tallene indikerer at mennesker og lokalsamfunn kan risikere å miste kontrollen over områder de enten har eid eller høstet fra, uten at de har fått noe tilbake i form av arbeidsplasser, infrastruktur, teknologi eller andre tjenester. I tillegg er det utvilsomt at politiske vedtak for å fremme økt produksjon av biodrivstoff, gjennom subsidieordninger og omsetningspåbud ${ }^{5}$ - som bidro til å vri produksjonen fra matproduksjon til biodrivstoffproduksjon - var en av mange årsaker til den betydelige økningen i matpriser som vi så i 2008. Prisene har i 2013 stabilisert seg på omtrent det samme høye nivået (FAO 2013).

Dette viser at et generelt press for omlegging til storskala landbruk ikke har hatt noen positiv utviklingseffekt, og det har hatt negativ effekt på mattilgangen for de mest sårbare. Mens promotering av mellomstore enheter er en del av matsikkerhetsmodellen, anbefaler de frivillige retningslinjene for landrettigheter, forankret i en matsikkerhetsstrategi, et tak for hvor store landeiendommer som kan selges (FAO 2012: avsnitt 12.6 og 15.2).

Derfor står matforetaksmodellen alene om å ønske en omlegging til storskala plantasjelandbruk. Jordreform for bedre fordeling av land er sentralt i matsuverenitetsmodellen, mens bedre tilgang til land er sentralt i matrettferdighetsmodellen. Innenfor retten til mat er statene pålagt å treffe tiltak for å «utvikle eller reformere landbrukssystemer» (FN 1966: artikkel 11.1a), noe som må forstås å omfatte jordreformer. I tillegg har vi sett at statene er særlig pålagt å ha oppmerksomhet på situasjonen for småbønder.

\section{Genmodifisering}

Uenighet om nytten av moderne genteknologi i landbruket var hovedgrunnen til at tre stater - USA, Canada og Australia (IAASTD 2009: 15) - og to selskaper - Monsanto og Syngenta (Nature 2008) - ikke støttet den endelige rapporten fra den største vitenskape- 
lige gjennomgangen av landbruksteknologi (International Assessment of Agricultural Knowledge, Science and Technology for Development, IAASTD).

Derimot støttet IAASTD agroøkologisk landbruk og sa at «selv de fattigste samfunnene har et potensiale gjennom økologisk landbruk og integrert sykdomsbekjempelse [integrated pest management] å ha tilsvarende eller større avlinger sammenlignet med konvensjonelle metoder» (IAASTD 2009: 43; FNs spesialrapportør på retten til mat 2011; Scoones 2009). I tillegg uttrykte rapporten en spesiell bekymring for at immaterialrettsbeskyttelse kunne hindre tilgang til frø og genetisk materiale, og gjøre bønder som opplever å få genmodifiserte og patentbeskyttede planter inn på sine åkre, rettslig ansvarlige overfor patenthaveren (IAASTD 2009: 8). Konklusjonene ble oppsummert av det internasjonale konsortiet for landbruksforskningssentra som å representere en markant endring fra tidligere tenkning (Consultative Group on International Agricultural Research 2008). Også kortere tematiske gjennomganger, noen med tittelen «Business as Usual is Not an Option», bekrefter dette inntrykket. ${ }^{6}$

Kjell Roland, direktør i Norfund, understreker betydningen av kommersialisering av landbruket: «Man er avhengig av kommersielle aktører for å få innført ny teknologi» (Utviklingsfondet 2012). Selv om Roland ikke direkte promoterer genmodifisering, altså at gener settes inn i organismer for å gi nye egenskaper, vil ny teknologi fra kommersielle selskaper ofte innebære genteknologi. Ingen frøselskaper vil ha insentiver til å produsere nye frø dersom de ikke har en rimelig utsikt til å kontrollere omsetningen av disse frøene.

Når kommersielle aktører løftes fram som den eneste løsningen, er dette en motsetning til den situasjonen som eksempelvis preget landbruket i USA i en tidlig fase. Statlige programmer for å bringe ut nye frøtyper og lære opp i nye dyrkingsmetoder var sentralt i ekspansjonen av landbruket rundt forrige århundreskifte. Først når bøndene hadde etablert en trygg økonomisk base med tilstrekkelig kunnskap og kompetanse, ble kommersielle frøleverandører introdusert. Den strategien som Roland promoterer, kan føre til at avlingene øker, men det er samtidig ingen tvil om at maktforholdet mellom frøselskapene og bøndene vil bli asymmetrisk.

I Norge har Nettverk for GMO-fri mat og fôr til nå lykkes i arbeidet med å hindre genmodifiserte organismer i landbruket, sist gang ved at regjeringen forbød Monsantos genmodifiserte rapslinje, som allerede er godkjent i EU/EØS-området (Miljøverndepartementet 2012).

Både matsikkerhetsmodellen og matforetaksmodellen er i prinsippet positive til genmodifisering, der både FAO og FN-resolusjoner fremmer bioteknologi - uten å uttrykke motstand mot genmodifisering (FAO 2009: avsnitt 26; FN 2004: avsnitt 2). De to øvrige skolene i rammeverket til Holt-Gimenéz er kategoriske motstandere av genteknologi. Genmodifisering står i kontrast til både ønsket om større uavhengighet fra selskapene, kulturelt akseptabel mat og agroøkologisk produksjonsform.

Retten til mat er interessant, siden den teknologioptimismen som dominerte på 1960tallet, også preger ordlyden i artikkel 11.2a i ØSK-konvensjonen (FN 1966), som pålegger statene å «forbedre metodene for fremstilling, oppbevaring og distribusjon av matvarer ved fullt ut å utnytte den tekniske og vitenskapelige kunnskap [...]». Gjennom formuleringen «fullt ut å utnytte den tekniske og vitenskapelige kunnskap» kan vitenskapelig 
kunnskap om genteknologi forstås å være omfattet. I nyere menneskerettighetsdokumenter er det ingen eksplisitt støtte til bruk av genteknologi (FAO 2004: avsnitt 8.5; FNs spesialrapportør for retten til mat 2011).

\section{Nedbygging av handelshindre}

En rapport fra Christian Aid (2007) viser at frihandel har ført til at u-landsmarkedene er blitt oversvømt med subsidierte og dumpede landbruksvarer, noe som har ødelagt den lokale næringsstrukturen (Paasch 2007). Selv om Verdens handelsorganisasjon (WTO) har vedtatt å avvikle alle former for eksportsubsidier innen 2013 (WTO 2005: avsnitt 6), ble eksempelvis massive generelle subsidieøkninger introdusert gjennom Farm Bill, vedtatt av den amerikanske kongressen i 2008 , altså tre år etter vedtaket om å avvikle eksportsubsidier.

Selv om Christian Aid kan kritiseres for å ha utelukkende lagt vekt på de negative konsekvensene av frihandel (Collier 2007; Fergusson 2007) og oversett de positive konsekvensene ved at landbruksprodukter blir lettere tilgjengelig på markedene til rike land, er det beregnet at det er særlig stater som Brasil, Argentina og Russland som vil tjene på en nedbygging av hindre for landbrukshandel (Wise 2009: 863), og videre at det er bønder som driver storskala landbruk som vil tjene på det, ikke bønder som driver småskala landbruk (Wise 2009: 863). De som fra før har størst ressurser og besitter mest informasjon, vil kunne nyttiggjøre seg de fordelene som en markedsåpning innebærer, mens de som er mest sårbare, vil kunne bli enda mer sårbare.

Argumentet til Christian Aid om at fattige land også må ha anledning til å heve tollsatsene dersom omstendighetene krever dette, er ikke annerledes enn det som var praksisen til de landene som opplevde industrialisering for 40 år siden (Sør-Korea), 80 år siden (Japan) eller 180 år siden (Storbritannia). Ha-Joon Chang argumenterer for at det er kun to stater som har praktisert frihandel mens de har hatt industrialisering, nemlig Sveits og Nederland. Disse valgte imidlertid å industrialisere uten et patentsystem, og de tillot dermed industrien å ta i bruk teknologi som var patentert i Tyskland - til store protester fra tysk næringsliv. Sveits og Nederland innførte patentbeskyttelse i henholdsvis 1907 og 1911 (Chang 2007).

Ofte vil økonomisk fattige stater ha offensive interesser innenfor handel med varer og dermed færrest mulige begrensninger på handelen. For økonomisk rike stater er det motsatt: De har offensive interesser innenfor blant annet immaterialrettsbeskyttelse, altså tidsbegrenset beskyttelse mot andres kommersielle bruk. Immaterialrettsbeskyttelse inkluderer patentering av genetisk materiale, som også kan omfatte materiale der urfolk og lokalsamfunn har utviklet en særegen kunnskap om nytteverdien av slikt materiale, omtalt som tradisjonell kunnskap. Rike stater vil i prinsippet stille strenge krav til produksjonen av varer, men ha færrest mulige begrensninger på tildeling og utøving av immaterialrettigheter.

Det er ingen av modellene som er imot handel med mat, men de skiller seg betydelig fra hverandre i synet på statenes rett til å bestemme sin egen handelspolitikk. Mens både 
matforetaksmodellen og matsikkerhetsmodellen handler om å bygge ned handelshindringer og redusere subsidier, er det sentrale for matrettferdighetsmodellen å fremme omsetningen av mat som er framstilt på særlig etiske eller økologiske måter. I matsuverenitetsmodellen er retten til å beskytte eget landbruk det sentrale.

I Norge er Utviklingsfondet en forkjemper for matsuverenitet, mens Kirkens Nødhjelp har vært med på å initiere en kampanje kalt «Nyt Afrika». Informasjonsleder i Utviklingsfondet skriver: «Der hvor vi skiller oss fra Nyt Afrika kampanjen er at vi mener at matsuverenitetsprinsippet også må gjelde for et land som vårt eget [...].» (Kroglund 2012). Det er samtidig langt fra slik at Nyt Afrika-kampanjen fremmer full frihandel med landbruksvarer (Bilden 2012). Kravet fra Nyt Afrika-kampanjen er snarere en radikal endring av rike lands landbruksstøtte, som fremmer et bærekraftig landbruk med mindre klimagassutslipp (Heggedal mfl. 2012). Kirkens Nødhjelp understreker at kortreist mat ikke nødvendigvis er mer miljøvennlig, og at landbrukspolitikken må styres ut fra hensyn til verdens fattige og miljøet. "Matsikkerhet i et klimaperspektiv», en strategi utviklet av Utenriksdepartementet i samarbeid med tre fagdepartementer, viser at disse to hensynene er sentrale også for Norge (Utenriksdepartementet 2012).

Til sist er det verdt å merke seg at ØSK-konvensjonen (FN 1966), artikkel 11.2b, sier at det er behovene som skal styre internasjonal handel med mat, men i nyere dokumenter framkommer en bred støtte til økt handel med mat (FAO 2004: del III, avsnitt 6-10). Samtidig er det grunn til å merke seg de nylig vedtatte Prinsipper for en menneskerettighetskonsekvensanalyse av handels- og investeringsavtaler (FNs spesialrapportør for retten til mat 2012; FNs menneskerettighetsråd 2012: avsnitt 42; United States Mission Geneva 2012). Her heter det at konsekvensanalyser av menneskerettigheter skal kunne medføre at den aktuelle avtalen enten blir revidert eller trukket tilbake, dersom en gjennomføring av en handels- og investeringsavtale gjør det umulig samtidig ivareta statens menneskerettighetsforpliktelser. Det er foreløpig for tidlig å si hvor mye disse retningslinjene faktisk vil bli brukt. Menneskerettighetene kan altså potensielt brukes til å revidere eller unnlate å ratifisere en handels- eller investeringsavtale.

\section{Hvorfor er landbruket blitt neglisjert?}

Landbruket er blitt neglisjert i mange land. Det viser seg blant annet i andelen av den samlede bistanden som har gått til landbruket. Andelen sank fra 17 til 3,8 prosent fra 1982 til 2006, for så å øke til 5,8 prosent i 2010 (FAO 2012b: 1). Dermed blir landbruket langt mindre produktivt enn det ville vært dersom staten faktisk hadde prioritert landbruket og innsett at landbruket har en essensiell rolle i sult- og fattigdomsbekjempelse. Det mest positive som kan sies om den rådende landbruksmodellen, er at den har lykkes i å øke produksjonen, men den har ikke bidratt til større matsikkerhet for de mest sårbare. Chang (2009) framholder at dagens rike land har noe å lære dagens fattige land, basert på deres egne erfaringer med omstilling av landbruket.

Mens Verdensbanken definitivt var involvert i nedprioriteringen av landbruket fram til 2007, representerte World Development Report 2008, som dette året handlet om land- 
bruket, en milepæl. Veksten i verdiskapingen (BNP) fra jordbruket ble funnet å være dobbelt så effektiv i å redusere fattigdom som BNP-vekst avledet fra andre sektorer, og BNPvekst med opprinnelse i landbruket gir langt større relative fordeler for den fattigste halvdelen av befolkningen enn for den rike halvdelen (Verdensbanken 2007: 6). ${ }^{7}$

Den økte oppmerksomheten på landbruket de siste årene skyldes blant annet matprisøkninger, en økende erkjennelse av klimaendringers innvirkning på landbruksproduksjonen og en bevissthet om at særlig Afrika sør for Sahara har hatt en lav vekst i produktiviteten.

Når vi skal finne forklaringer på at landbruket er blitt stemoderlig behandlet, må vi huske at beslutningstakeres preferanser er formet av egen maktposisjon og ønske om å beholde disse posisjonene, men også av økonomiske og ideologiske forhold.

Den antakelig viktigste forklaringen på at landbruket er blitt neglisjert, omtales ofte som «urban bias». Det er i storbyene de mektigste bor, og det er her politikerne må sikre sin innflytelse, bygge nettverk og investere ressurser. I tillegg forstås byen å representere framtiden, mens landsbygda representerer fortiden.

Samtidig er det ingen tvil om at statens oppgave er å legge til rette for differensiering av næringslivet. Det å ha mange bønder er ikke et mål i seg selv. Stater med den største andelen bønder er samtidig stater med den største andelen som sulter. Den enkleste måten å forklare dette på er å vise til ulike produktivitetseffekter i industrien og i landbruket. Skalaeffekter - som handler om at det er mye billigere å produsere vare nr. 1000000 enn vare nr. 1 - kjennetegner industriproduksjon på en helt annen måte enn landbruksproduksjon. For at den nødvendige diversifiseringen av næringslivet skal skje, må det være et samspill mellom myndigheter, investorer og entreprenører. Økt overskudd hos den enkelte bonde er en viktig forutsetning for at dette samspillet faktisk kan skje, og det krever at det satses på landbruket. Det er altså ikke slik at verken næringsmessig omstilling eller økonomisk vekst skjer best ved å neglisjere landbruket.

Videre er det opplagt at selve innholdet i retten til mat, slik det er blitt definert i artikkel 11.2 i ØSK-konvensjonen (FN 1966), er blitt ignorert. Her vil vi bare løfte fram at internasjonalt samarbeid vektlegges i konvensjonen. Det er vist at avkastningen ved å investere i å utvikle bedre frø og metoder i landbruket er svært høy, ofte over 60 prosent (von Braun mfl. 2008). Likevel har slikt samarbeid ikke fått de nødvendige økonomiske ressursene de siste tiårene. Fra 1980-tallet reduserte statene budsjettene til landbruksforskning og la til rette for at private selskaper skulle få bedre rammebetingelser for sin forskning, blant annet ved å tillate patenter på bioteknologiske oppfinnelser. Videre ble det antatt at private aktører var mer effektive enn statlige organer i å få de nye produktene ut til bøndene. Problemet oppstår når kommersielle leverandører lykkes i å oppnå tilnærmet monopolmakt på lokale markeder, og når myndighetene verken har effektiv lovgivning for å hindre misbruk av monopolmakt eller rådgivingstjenester for å gi bøndene et bedre beslutningsgrunnlag.

Mens menneskerettighetsrealisering handler om å sikre trygghet og verdighet for alle mennesker, er det ingen tvil om at de maktstrukturene som preger landsbygda i mange utviklingsland, er et effektivt hinder for at beskyttelse og myndiggjøring faktisk kan skje. Slike maktstrukturer hindrer nødvendige reformer, og i mange tilfeller er det slik at per- 
soner med makt faktisk tjener på andres sult (Skarpeteig 2004). Når landarbeidere må fallby sin arbeidskraft til godseiere eller andre storbønder, og når mennesker holdes utenfor beslutningsprosessene, kan utbyttende strukturer opprettholdes. Dette skjer selv om slike former for undertrykking opplagt er negativt for samfunnet som helhet, blant annet ved at den nasjonale kjøpekraften holdes nede. De privilegerte må erkjenne at økonomisk og sosial utvikling også vil gagne dem selv, dersom de evner å omstille seg til en ny virkelighet med ansvarliggjørende institusjoner og selvbevisste borgere.

De mange initiativene for økt landbruksproduksjon som er initiert de siste årene, har definitivt gitt landbruket - særlig i Afrika - etterlengtet oppmerksomhet. Økt matproduksjon er nødvendig. Samtidig er det grunn til å se kritisk på hvordan denne økte produksjonen skjer, og dermed også hvordan matsikkerhet faktisk defineres. Nærstad kritiserer mandatet til en evaluering av norsk landbruksbistand, der det sentrale er å undersøke virkningen på matsikkerhet (Nærstad 2012; Norad 2012). Siden matproduksjonen pr. årsverk på en plantasje kan være formidabel, kan slik produksjon bli evaluert som bra, selv med negative sosiale konsekvenser og miljøkonsekvenser (økt bruk av kunstgjødsel, miljøgifter og vann). Tilsvarende kan matproduksjon som skjer på miljømessig bærekraftige måter, men som produserer mindre mat pr. årsverk, bli - slik Nærstad (2012) ser det - vurdert som dårlig. Nærstads ønske er at evalueringen også må omfatte miljømessige og sosiale forhold. Uansett om han har rett eller ikke i sin kritikk av mandatet for evalueringen, må vi unngå en landbruksutvikling som ødelegger livsgrunnlag og levekår for lokalsamfunn.

\section{Avslutning}

I denne artikkelen har jeg forsøkt å vise at debatten om hvordan landbruket kan innrettes for å utrydde sult, kan presenteres gjennom en motsetning mellom to hovedretninger. Den første retningen vektlegger økt matproduksjon, gjerne med bruk av patentert bioteknologi eller genmodifisert teknologi, og økt handel med mat. Den andre retningen legger også vekt på produktivitetsvekst, men argumenterer for at dette best kan skje ved at staten i langt større grad tilrettelegger for småbøndene, og derigjennom oppfyller sine menneskerettighetsplikter.

Artikkelen vektlegger at staten må være en god tilrettelegger, at det har vært en manglende satsing på å realisere retten til mat, og at en menneskerettighetstilnærming også må innebære en helt annen vekt på beslutningsprosessen.

Et rammeverk for å kategorisere matregimer (Holt-Giménez 2010) er bare én av mange mulige kategoriseringer, og synliggjør som nevnt ikke retten til mat som en egen retning. Likevel er det grunner til at «retten til mat» er vel så dekkende og anvendelig som begrepet «matrettferdighet». Det faktum at myndiggjøring er valgt som det sentrale stikkordet, og at virkemiddelet er mobilisering av lokale organisasjoner, faller direkte inn i kjernen av en menneskerettighetstenkning. Det kan også argumenteres for at begrepet matrettferdighet er vanskeligere å operasjonalisere, og at strategier for å virkeliggjøre matrettferdighet er vanskelig å enes om mellom ulike bevegelser, slik debatten om kort- 
reist vs. langreist mat viser. Som en følge av den økte oppmerksomheten som er gitt retten til mat det siste tiåret - som følge av prosesser primært innenfor FAO og FNs menneskerettighetsråd samt FNs komité for økonomiske, sosiale og kulturelle rettigheter (CESCR) - er det sannsynlig at langt flere vil gjenkjenne retten til mat som det sentrale framfor matrettferdighet. Retten til mat har også påvirket forståelsen av matsikkerhet (FAO 2004) og matsuverenitet (FN 1966: artikkel 1.2).

Artikkelen har vist at konsekvensene av en større omlegging til plantasjelandbruk, som er sentralt i matforetaksmodellen, ikke er en egnet strategi dersom bedre mattilgang for de mest sårbare og marginaliserte er målet. Selv om plantasjebasert landbruksproduksjon er utbredt i land som Brasil eller Kenya, bør slik produksjon ikke promoteres i land som er basert på småskala landbruk.

For de andre regimene er det ingen tvil om at «slow food», matsikkerhet, retten til mat og matsuverenitet appellerer til ulike grupper. Likevel er det grunnlag for å hevde a å ta utgangspunkt i rettslig bindende standarder som statene selv har formulert, men ikke tatt tilstrekkelig hensyn til, har det beste potensialet i det videre arbeidet med å løse verdens sultproblem.

\section{Noter}

${ }^{1}$ Denne artikkelen brukes begrepet sult («hunger»), ikke sultkatastrofe («famine», forstått som alvorlig matmangel med betydelig økning i dødeligheten) eller utsulting («starvation»), som Sen (1981: 1, utheving i original) definerer som «some people not having enough food», eller «kronisk underernæring». For gode begrepsavklaringer, se Banik (2007).

${ }^{2}$ Hovedforskjellen er at 1996-målsettingen vil ha en halvering av antallet, som altså betyr en reduksjon fra omtrent 800 millioner til 400 millioner. 2000-målsettingen bruker andelen og bruker 1990 som startår. Da var folktallet i verden 5,1 milliarder, og det var 850 millioner mennesker som led av sult, noe som med et folketall på 7,2 milliarder i 2015 innebærer at målet nås dersom 600 millioner lider av sult. For en oversikt over tallet på dem som lider av sult, se FAO (2010).

${ }^{3}$ Ifølge en rapport fra Oxfam (Murphy mfl. 2012: 9) kontrollerer de fire selskapene Archer Daniels Midland (ADM), Bunge, Cargill og Louis Dreyfus minst 70 prosent av verdens soya- og kornhandel. Flere nye initiativer søker å promotere private selskapers rolle for å hindre sult og fremme ernæring, f.eks. «New Alliance for Food Security and Nutrition» i regi av G8 og «New Vision for Agriculture» og «Grow Africa Partnership» i regi av World Economic Forum. For en kritikk av disse initiativene, se GRAIN (2013).

${ }^{4}$ Erik Solheims omfavnelse av Paul Collier («bekrefter mitt syn på hva som er problemer og løsninger») skapte også en norsk debatt, se RORG (2007).

${ }^{5}$ Merk at EU-kommisjonen i 2012 foreslo et direktiv som skulle redusere biodrivstoff fra matplanter til 5 prosent av alt biodrivstoff i 2020, og kutte ut subsidier til denne typen biodrivstoff fra samme år, med følgende begrunnelse: «Advanced biofuels, such as those made from wastes and algae [...] do not compete directly for agricultural land for the food and feed markets. It is appropriate, therefore, to encourage greater production of such advanced biofuels» (EU-kommisjonen 2012: 7).

${ }^{6}$ For alle rapportene og presentasjonene til IAASTD: http://www.agassessment.org/

${ }^{7}$ Disse funnene gir imidlertid ikke utslag i anbefalinger om en annen politikk i Verdensbanken, som vist i en rekke artikler i Journal of Peasant Studies, 36 (3). 


\section{Referanser}

Anseeuw, W., Alden Wily, L., Cotula, L. \& Taylor, M. (2012) Land rights and the rush for land, findings of the global commercial pressures on land research project. Roma: International Land Coalition.

Banik, D. (2007) Starvation and India's democracy. London: Routledge.

Bilden, K.M. (2012) Frihandel gjør vondt verre. Oslo: Kirkens Nødhjelp. Lastet ned 3. januar 2013 fra: www.kirkensnodhjelp.no/blogg/utviklinger/kaare-m-bilden/dates/2012/12/frihandel-gjorvondt-verre/

CESCR (1991) General Comment No 3: The Nature of States Parties' Obligations (Art. 2, Para. 1, of the Covenant). UN doc. E/1991/23, s. 83-87. Genève: FNs komité for økonomiske, sosiale og kulturelle rettigheter (CESCR).

CESCR (2000) General Comment No. 12: The right to adequate food (Art. 11 of the Covenant). UN doc E/2000/22, s. 102-110. Genève: FNs komité for økonomiske, sosiale og kulturelle rettigheter (CESCR).

CESCR (2009) Guidelines on treaty-specific documents to be submitted by states parties under Articles 16 and 17 of the International Covenant on Economic, Social and Cultural Rights, E/C.12/ 2008/2. Genève: FNs komité for økonomiske, sosiale og kulturelle rettigheter (CESCR).

Chang, H.-J. (2007) Bad samaritans: Rich nations, poor policies and the threat to the developing world. London: Random House.

Chang H.-J. (2009) Rethinking public policy in agriculture: Lessons from history, distant and recent. Journal of Peasant Studies, 36 (3), s. 477-515.

Christian Aid (2005) The economics of failure. The real cost of 'free' trade for poor countries. London: Christian Aid.

Collier, P. (2007) The bottom billion: Why the poorest countries are failing and what can be done about it. Oxford: Oxford University Press.

Collier, P. (2008) Politics of hunger: How illusion and greed fan the food crisis. Foreign Affairs, 87, s. $67-80$.

Consultative Group on International Agricultural Research (2008) A session on global challenges: New initiatives to harness the power of agricultural science. CGIAR News, desember 2008. Lastet ned 3. januar 2013 fra: www.cgiar.org/enews/december2008/story_02_print.html

Cotula, L. (2012) The international political economy of the global land rush: A critical appraisal of trends, scale, geography and drivers. Journal of Peasant Studies, 39 (3-4), 649-680.

CROP (2013) Poverty \& the Millennium Development Goals (MDGs): A critical assessment and a look forward. CROP Poverty Brief, januar 2013. Bergen: Comparative Research Programme on Poverty (CROP).

Deininger, K. \& Byerlee, D. (2010) Rising global interest in farmland. Can it yield sustainable and equitable benefits? Washington D.C.: Verdensbanken.

Eide, A. (1987) Report on the right to adequate food as a human right. E/CN.4/Sub.2/1987/23 [også utgitt som Human Rights Study Series No. 1, United Nations publications Sales No. E.89.XIV.2: Right to adequate food as a human right].

EU-kommisjonen (2012) Proposal for a Directive of the European Parliament and of the Council amending Directive 98/70/EC relating to the quality of petrol and diesel fuels and amending Directive 2009/28/EC on the promotion of the use of energy from renewable sources, EU $\operatorname{COM}(2012) 595$ final. Brussel: EU-kommisjonen.

FAO (1996) World food summit plan of action. Roma: FNs organisasjon for mat og landbruk (FAO). 
FAO (2004) Voluntary guidelines to support the progressive realization of the right to adequate food in the context of national food security. Adopted by the 127th Session of the FAO Council. Roma: FNs organisasjon for mat og landbruk (FAO).

FAO (2007) Right to food and indigenous peoples. Roma: FNs organisasjon for mat og landbruk (FAO). Lastet ned 3. januar 2013 fra www.fao.org/righttofood/wfd/pdf2007/ focus_indigenous_eng.pdf

FAO (2009) WSFS 2009/2: Declaration of the World Summit on Food Security. Roma: FNs organisasjon for mat og landbruk (FAO).

FAO (2010) Global hunger declining, but still unacceptably high. Roma: FNs organisasjon for mat og landbruk (FAO). Lastet ned 3. januar 2013 fra: www.fao.org/docrep/012/al390e/al390e00.pdf

FAO (2012a) State of food insecurity in the world 2012. Roma: FNs organisasjon for mat og landbruk (FAO).

FAO (2012b) Funding for programmes up 28 percent. Roma: FNs organisasjon for mat og landbruk (FAO). Lastet ned 3. januar 2013 fra: www.fao.org/fileadmin/user_upload/ resource_mobilization/docs/Funding_for_programmes_up_28_percent.pdf

FAO (2012c) Voluntary guidelines on the responsible governance of tenure of land, fisheries and forests in the context of national food security. Vedtatt av Committee on World Food Security. Roma: FNs organisasjon for mat og landbruk (FAO).

FAO (2013) FAO food price index. Roma: FNs organisasjon for mat og landbruk (FAO). Lastet ned 12. mars 2013 fra: www.fao.org/worldfoodsituation/wfs-home/foodpricesindex/en/

Fergusson, N. (2007) The least among us. New York Review of Books, 1. juli 2007. Lastet ned 3. januar 2013 fra: www.nytimes.com/2007/07/01/books/review/Ferguson-t.html?pagewanted=all\&_r=0

FN (1966) FNs internasjonale konvensjon om økonomiske, sosiale og kulturelle rettigheter. Generalforsamlingsresolusjon 2200A (XXI). Vedtatt 16. desember 1966 (trådte i kraft 1976). New York: FN.

FN (2003) The human rights based approach to development cooperation towards a common understanding among UN agencies. New York: FN. Lastet ned 3. januar 2013 fra: www.undg.org/ archive_docs/6959-

The_Human_Rights_Based_Approach_to_Development_Cooperation_Towards_a_Commo n_Understanding_among_UN.pdf

FN (2004) A/RES/58/200, Science and technology for development. New York: FN.

FN (2012a) Global partnership key to achieving Millennium Development Goals by 2015. UN report. New York: FN. Lastet ned 3. januar 2013 fra: www.un.org/apps/news/ story.asp? NewsID $=42372 \& \mathrm{Cr}=\mathrm{mdg} \& \mathrm{Cr} 1=$

FN (2012b) The Millennium Development Goals report 2012. New York: FN.

FNs menneskerettighetsråd (2012) The right to food. A/HRC/RES/19/7. Genève: FNs komité for økonomiske, sosiale og kulturelle rettigheter (CESCR).

FNs spesialrapportør for retten til mat (2011) Report submitted by the Special rapporteur on the right to food, Olivier De Schutter. A/HRC/16/49. Genève: FN.

FNs spesialrapportør for retten til mat (2012) Guiding principles on human rights impact assessments of trade and investment agreements, A/HRC/19/59/Add.5. Genève: FN.

Friedmann, H. (1993) The political economy of food: A global crisis. New Left Review, 197, s. 2957.

GRAIN (2013) The G8 and land grabs in Africa. Lastet ned 8. april 2013 fra: www.grain.org/article/ entries/4663-the-g8-and-land-grabs-in-africa

Haugen, H.M. (2009) Food sovereignty - an appropriate approach to ensure the right to food? Nordic Journal of International Law, 78 (3), s. 263-292. 
Haugen, H.M. (2011) Human rights principles: Can they be applied to improve the realization of social human rights? I Max Planck Yearbook of United Nations Law, vol. 15, s. 419-444. Leiden \& Boston: Martinus Nijhoff.

Heggedal, E., Jensen, N.K., Hermstad, A. \& Helland, A.-M. (2012) En bærekraftig visjon. Aftenposten, 15. oktober 2012.

Holt-Giménez, E. (2010) Food security, food justice, or food sovereignty? FoodFirst Backgrounder, 16 (4). Lastet ned 3. januar 2013 fra: http://international.uiowa.edu/files/ file_uploads/FoodMovementsWinter2010bckgrndr.pdf

Holt-Giménez, E. \& Shattuck, A. (2011) Food crises, food regimes and food movements: Rumblings of reform or tides of transformation? The Journal of Peasant Studies, 38 (1), s. 109-144.

IAASTD (2009) Synthesis report. A synthesis of the global and sub-global IAASTD reports. Washington D.C.: Island Press.

Kroglund, A. (2012) Utvikling, handel og bærekraft. Dagsavisen, 5. november 2012. Lastet ned 12. mars 2013 fra: www.dagsavisen.no/nyemeninger/alle_meninger/cat1002/subcat1041/ thread258665/\#post_258665

Maastricht Principles (2012) Maastricht principles on extraterritorial obligations of states in the area of economic, social and cultural rights. Maastricht: Maastricht University \& Den internasjonale juristkommisjonen.

McMichael, P. (2009) A food regime genealogy. The Journal of Peasant Studies, 36 (1), s. 139-169.

Miljøverndepartementet (2012) Endring av forskrift om forbud mot omsetning i Norge av bestemte genmodifiserte produkter. Oslo: Miljøverndepartementet. Lastet ned 3. januar 2013 fra: www.regjeringen.no/pages/38165842/Kgl_res_genmodifisert_GT73_raps_121214.pdf

Nature (2008) Deserting the hungry? Editorial. Nature, 451, s. 223-224.

Norad (2012) Terms of reference: Evaluation of the contribution of Norway's bilateral agricultural support to food security. Oslo: Norad.

Nærstad, A. (2012) Snever Norad-evaluering av landbruksbistand. Bistandsaktuelt, 10.

Paasch, A. (red.), Garbers, F. \& Hirsch, T. (2007) Trade policies and hunger. The impact of trade liberalisation on the right to food of rice farming communities in Ghana, Honduras and Indonesia. Genève: Ecumenical Advocacy Alliance.

Murphy, S., Burch, D. \& Clapp, J. (2012) Cereal secrets. The world's largest grain traders and global agriculture. Oxford: Oxfam GB. Lastet ned 12. mars 2013 fra: www.oxfam.org/sites/ www.oxfam.org/files/rr-cereal-secrets-grain-traders-agriculture-30082012-en.pdf

RORG (2007) På rett vei med Paul Collier? Lastet ned 3. januar 2013 fra: www.rorg.no/Artikler/ 1662.html

Scoones, I. (2009) The politics of global assessments: The case of the international assessment of agricultural knowledge, science and technology for development (IAASTD). The Journal of Peasant Studies, 36 (3), s. 547-571.

Sen, A. (1981) Poverty and famines: An essay on entitlements and deprivation. Oxford: Clarendon Press.

Skarpeteig, M.I. (2004) Noen tjener på andres sult. I Mennesker kjemper for livet-Menneskeverd og menneskerettigheter i en globalisert verden, red. K. Fretheim, s. 58-71. Oslo: Verbum.

UNICEF (FNs barnefond), WHO (Verdens helseorganisasjon) \& Verdensbanken (2012) Levels and trends in child malnutrition, joint child malnutrition estimates. New York, Genève \& Washington D.C.: UNICEF, WHO \& Verdensbanken.

United States Mission Geneva (2012) U.S. joins consensus on HRC resolution on the right to food. Lastet ned 3. januar 2013 fra: http://www.humanrights.gov/2012/03/23/us-joins-consensuson-hrc-resolution-on-the-right-to-food/

Utenriksdepartementet (2009) St.meld. nr. 13 (2008-2009) Klima, konflikt og kapital. Norsk utviklingspolitikk $i$ et endret handlingsrom. Oslo: Utenriksdepartementet. 
Utenriksdepartementet (2012) Matsikkerhet i et klimaperspektiv. Strategi 2013-2015. Oslo: Utenriksdepartementet. Lastet ned 3. januar 2013 fra: www.regjeringen.no/upload/UD/Vedlegg/ matsikkerhet_2012.pdf

Utviklingsfondet (2012) Hvor mange bønder trenger vi? Lastet ned 3. januar 2013 fra: http:// www.utviklingsfondet.no/nyheter/hvor-mange-bnder-trenger-vi/

Verdensbanken (2007) World development report 2008: Agriculture for development. Washington D.C.: Verdensbanken.

Von Braun, J., Fan, S., Meinzen-Dick, R. Rosegrant, M.W. \& Pratt, A.N. (2008) International agricultural research for food security, poverty reduction, and the environment. What to expect from scaling up CGIAR investments and «Best Bet» programs. Washington D.C.: International Food Policy Research Institute.

Wise, T.A. (2009) Promise or pitfall? The limited gains from agricultural trade liberalisation for developing countries. Journal of Peasant Studies, 36 (4), s. 855-870.

WTO (2005) WT/MIN(05)/DEC, Ministerial declaration. Genève: Verdens handelsorganisasjon (WTO). 